\title{
The Effect of Talent Management Process on the Research Performance of Faculty Members with the Mediating Role of Organizational Justice
}

\author{
Farzaneh Eghbal ${ }^{\text {a }}$ \\ PhD Student, Educational Administration, Faculty of Education and Psychology, f.eghbal.ui.ac.ir@gmail.com \\ Reza Hoveida ${ }^{\text {a }}$ \\ Associate Professor, Educational Administration, Faculty of Education and Psychology, r.hoveida@edu.ui.ac.ir \\ Seyed Ali Siadat Seyadat ${ }^{\text {a }}$ \\ Professor, Educational Administration, Faculty of Education and Psychology, s.a.siadat@edu.ui.ac.ir \\ Hossein Samavatyan ${ }^{\text {a }}$ \\ Associate Professor, Faculty of Education and Psychology, h.samavatian@edu.ui.ac.ir \\ Mohammad Hossein Yarmohammadian ${ }^{b}$ \\ Professor, Health Management and Economic Research Center, \\ mhyarm@yahoo.com

\footnotetext{
${ }^{a}$ University of Isfahan, Isfahan Province, Isfahan, P.O. Box 146, Daneshgah Street, Isfahan, 81746-73441, Iran.

${ }^{\mathrm{b}}$ Isfahan University of Medical Sciences, P.O. Box 319, Hezar-Jerib Ave., Isfahan 81746 73461, Iran.
}

\begin{abstract}
$\mathrm{T}$ The research performance of faculty members is one of the main criteria for measuring a university's overall performance, and universities and higher education centers seek to improve research because of their purpose and their commitment to various parts of society. The present research aims at determining the effects of the components of perceived talent management on the research performance of faculty members with the mediating role of perceived organizational justice. The research is a correlationaldescriptive study based on structural equations and its statistical population consists of the faculty members at the University of Isfahan, Isfahan University of Medical Sciences and Isfahan University of Technology.

For the sample size, using the SPSS Sample Power software, of 562 individuals 130 were selected using stratified random sampling proportional to sample size. For data collection, faculty members' research performance

record, a talent management questionnaire and a perceived organizational justice questionnaire were used. Convergent validity for both questionnaires (AVE) was calculated to be more than 0.5 and the reliability of both questionnaires using Cronbach's alpha coefficient was calculated to be more than 0.75 . Data analysis was performed using the Smart PLS 3.2.6 statistical software.

Findings indicated that the components of the variables of perceived talent management and perceived organizational justice account for a total of $61 \%$ of the variance of the variable of research performance variable and the mediating role of the variable of perceived organizational justice variable was found to be insignificant. As a result, it can be said that the improvement of talent management processes can lead to increased faculty members' increased sense of organizational justice and ultimately improved research performance.
\end{abstract}

\section{Keywords:}

perceived talent management; perceived organizational justice; research performance; faculty members.
Citation: Eghbal F., Hoveida R., Seyadat S.S., Samavatyan H., Yarmohammadian M.H. (2017) The Effect of Talent Management Process on the Research Performance of Faculty Members with the Mediating Role of Organizational Justice. Foresight and STI Governance, vol. 11, no 2, pp. 83-91. DOI: 10.17323/2500-2597.2017.2.83.91 
$\mathrm{U}$ niversities and higher education centers are important organizations that play a strategic role in accomplishing a country's goals and are expected to create knowledge and educate a specialized and committed workforce required by the country. Here, faculty members are considered the critical factors determining the country's education system and their performance requires serious study and attention. One of the key factors of the productivity of universities and their employees and the criteria for evaluating that productivity is the academic research performed by university lecturers. Players on the higher education market strive to improve their research indicators in line with their goals and obligations to society at large. According to Zainab [Zainab, 2000], research performance will strengthen society's confidence in a university, increase the university's prestige and lend a synergetic effects to the development of science and creation of knowledge.

Ramsden [Ramsden, 1994] believes that the critical challenges facing universities include faculty members' teaching responsibilities, research performance, and research quality and resource constraints. Research is closely related to the quality of education, and in recent decades has received much attention. Levin \& Stephan [Levin, Stephan, 1998] believe that people who evaluate the performance of educational institutes, have many concerns about future research quantity and quality. Research performance for the promotion of faculty members is a necessary component, and when assessing the career advancement of these individuals, studies performed by them become critical. Other key aspects for assessing faculty members and their prospects for promotion are their level of knowledge, research performance and received rewards [Badri, Abdulla, 2004]. Universities and higher education institutions seek to improve the research performance of their faculty members by taking measures such as holding training workshops for them, providing study opportunities, giving them material incentives as well as incentives for self-improvement, while promoting their academic position in society at large. Gething \& Larthaepin [Gething, Larthaepin, 2000] state that evaluation of the performance of faculty members usually takes place through peer review of their published papers, and evaluating one's participation in academic conferences and research projects. While teaching and other activities are evaluated successively, faculty members can only achieve success in their educational duties once they have already established themselves as successful researchers, who can then use their research results in the classroom.

On the other hand, according to recent studies, several factors affect individual and organizational performance, including talent management methods at organizations [Kagwiria, 2013]. Salehzadeh \& Labaf [Salehzadeh, Labaf, 2011] consider the reasons why there has been such a focus on talent management in recent years. They considered the direct relationship between talent management methods and superior organizational performance, the use of talent for value amid such changing factors as the complex and dynamic business environment, increased expectations from the board of directors, the change in employees' expectations, and the evolving structure of workforce.

Therefore, the talent management system at universities must observe heightened standards for the employment of faculty members. This system must also identify and attract the best academic talent and ensure proper conditions for the employment of enthusiastic individuals to become members and cooperate in university faculties. In fact, talent management is the most important competitive advantage at modern organizations and the identification of talent is considered the most important task for human resource management [Sayadi et al., 2011].

Huselid, Beatty \& Becke [Huselid et al., 2010] state that all individuals have certain talents that must be uncovered and identified. By using talent management, it is possible to ensure that each employee will be placed in a position tailored to his/her special talents and abilities.

Sweem [Sweem, 2009] believes that talent management is an intelligent approach to the attraction, development and retention of experts and the use of their talents and competencies to meet an organization's needs and achieve present and future goals. Talent management is a collection of designed processes that guarantee employees' proper placement at an organization. In other words, the right person will be in the right job at the right time.

Various talent management models in the literature have been designed by various experts and theorists, and in each of these models, different elements have been highlighted as the most important for organizational and environmental demands. A model designed by Peter Cheese, Robert Joseph Thomas, and Elizabeth Craig [Cheese et al., 2008] in this field includes five main components that indirectly cover other models. The first of these five main components is "defining and identifying talent needs": the first step in creating a human resource strategy is to fully understand an organization's development strategy and determine the number of personnel and which competencies and skills are needed for effectively reaching long-term goals. Most of all, this involves an analysis and clear understanding of the organization's available talents. The second one is, "discovering talent sources", which involves defining and identifying talent needs based on the organization's goals.

The third component is "developing talent potential", which is the ability to continuously develop individual and group knowledge, skills, and behavioral patterns to improve the overall capabilities of the organization as a whole. In other words, talent development should guarantee that employees continuously acquire new skills and abilities, expand the opportunities available to them and prepare them to accept new roles and responsibilities [Cheese et al., 2008]. According to [Rezaian, Soltani, 2009], the important thing at this stage 
is organizational support through the creation of good career trajectories and opportunities for professional growth.

"The strategic deployment of talent", the fourth component, involves deploying the appropriate personnel to necessary positions at the right time, which allows an organization to effectively implement its strategies and prepare for future challenges and opportunities.

Finally, the fifth component, the "measurement and alignment" of talent management activities, is the most important factor supporting the cycle or process of talent management. The power of this talent management process model lies in its dynamic integration of demand for talent, its identification, discovery and use, and its emphasis on bringing personnel potential into line with the overall strategy of an organization [Cheese et al., 2008].

Eghbal et al. [Eghbal et al., 2016] developed a model entitled "the management of gifted personnel at talentcentered universities". The authors identified two components in this process: the attraction and retention of talent, and state that after the discovery of talent, the two aforementioned components are the most important aspects of talent management. In order to deploy talent, which was discovered using reliable indicators, to accomplish organizational goals, measures must be taken to retain talented individuals by keeping employee turnover rates low.

Theoretical developments and empirical research suggest that the performance of faculty members is directly tied to talent management process at a university. Therefore, in our research, faculty members' perception of university management will be investigated. We assume that other variables (in particular, organizational justice) can be placed in chains of causes and effects between independent and dependent variables and influence the results of research.

Neal McNabb $[M c N a b b, 2009]$ coined the term "organizational justice" to describe the relationship between an employee and a system of sanctions and incentives at an organization, and to study its role in a working environment. In fact, the term "perceived organizational justice" describes the direct contribution of the role of justice as an element of this work environment. How employees feel they are treated at work influences other performance variables. In general, perceived organizational justice includes components that distinguish it from actual organizational justice, namely distributive justice, procedural justice and interactional justice, each of which influences the behaviors and performance of employees [McDowall, Fletcher, 2004]. Several studies on justice at organizations have traditionally focused on the distribution of work-related pay or bonuses according to the theory of equity in social exchange [Adams, 1963].

"Distributive justice" refers to perceived justice of outputs and outcomes that people receive. Of course, distributive justice is not only limited to fair pay but also an extensive collection of organizational outcomes such as promotions, rewards, work plans, benefits and performance evaluations. Poor behavior by employees must entail a fair punishment [Lambert, 2003].

"Procedural justice" refers to fair interpersonal relationships related to organizational procedures [McDowall, Fletcher, 2004]. Studies show that procedures become fair when used consistently without considering individual attributes or personal privileges, and procedures are considered fair when they are based on accurate information and by considering the interests of all participating organizational units along with the adherence to ethical criteria and norms [Lambert, 2003].

"Interactional justice" concerns fairness in interpersonal interactions and is focused on the individual dimension of organizational activities, particularly management behaviors and communication with employees. Interactional justice envisages honesty, sympathy and respect in communication and the justifications for decisions taken at an organization [McDowall, Fletcher, 2004].

The theory of perceived organizational justice states that honesty and fairness are considered the most critical factors in a work environment, these factors are a fundamental and necessary basis for the effectiveness of organizational processes. Employee perception of equality and sincerity in their treatment is an important element that influences other work-related variables. Therefore, the vital significance of organizational justice is difficult to overstate because an organization's survival and prosperity depend on it [Lambert, 2003]. The establishment of perceived organizational justice can lead to an improved work environment and increased confidence in an organization. For this reason, universities, as have other organizations have, have relied on organizational justice and its outcomes to prevent internal and environmental negative factors [Avital, Collopy, 2001].

Research performance is also considered one of the fundamental dimensions of university and faculty members' performance and is affected by the faculty members' perception of talent management. The university staff's perception of organizational justice can influence indicators of educational and teaching activity, which further confirms the relevance of studying these processes and ways to improve them.

Therefore, these issues pushed us to investigate the effect of perceived talent management on the research performance of universities' faculty members, which is the main asset of any university. At the same time, we consider the mediating role of perceived organizational justice and will determine the contribution of each related component.

Based on our conceptual research model (Figure 1), faculty members' research productivity is evaluated in line with their views of the talent management process. This process includes such components as defining 


\section{Figure 1. Conceptual research model}

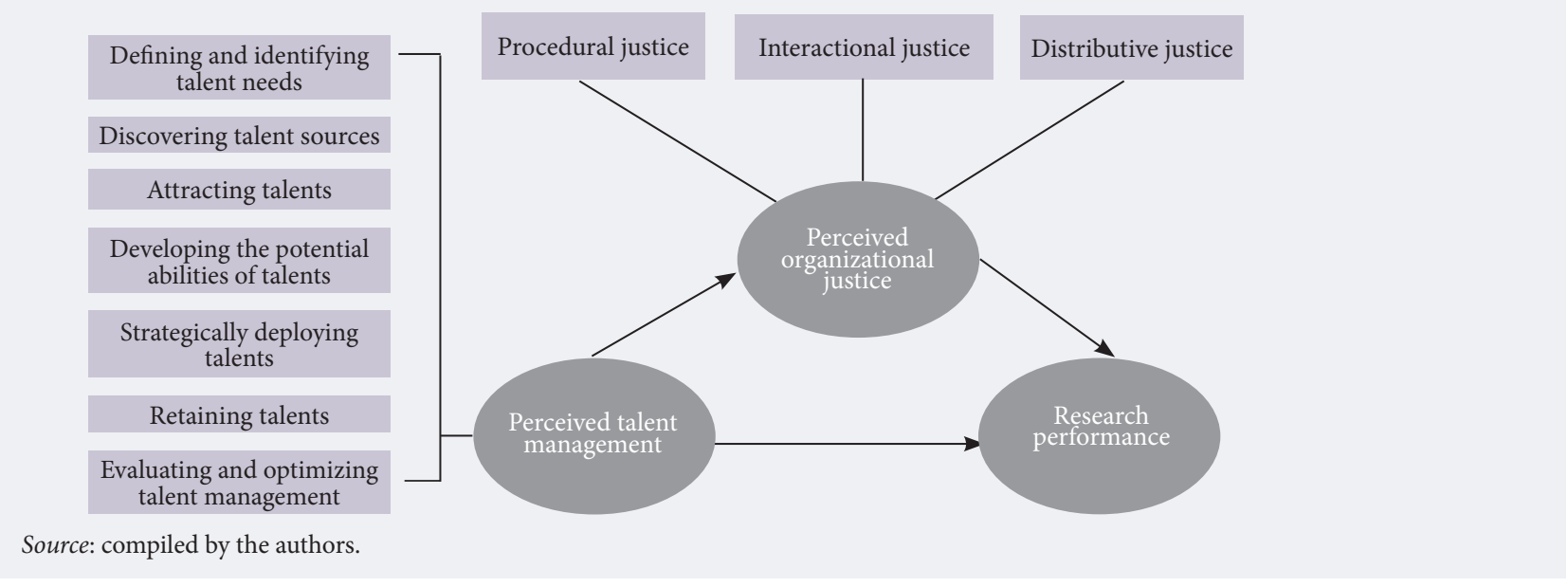

and identifying talent needs, the search for talent, attracting talent, developing talent potential, strategically deploying talent, retaining talent, evaluating employees' activity and the selection of optimal positions for talent. This analysis directly or indirectly touches upon perceived organizational justice, including its distributive, procedural and interactional aspects.

In order to design the conceptual research model, the talent management process model of Cheese, Thomas, Craig [Cheese et al., 2008; Eghbal et al., 2016] and the perceived organizational justice model [Niehoff, Moorman, 1993] were used (see Figure 1).

A series of studies [Lambert, 2003; Jiang, Iles, 2011; Gelens et al., 2014; Kagwiria, 2013; Salehzadeh, Labaf, 2011] by various methods came to a similar conclusion about the enormous effect talent management has on individual and group productivity, using perceived organizational justice as a key mediating factor. Varying employee performance depends on the effectiveness of talent management processes and their perceptions of organizational justice.

\section{Methodology}

The present research is a correlational-descriptive study and its modeling is based on structural equation modeling. The statistical population of this research consists of the faculty members of selected public universities of Isfahan who were employed during the years 2010-2015. The sample encompasses the University of Isfahan (UI), Isfahan University of Medical Sciences (IUMS) and the Isfahan University of Technology (IUT) and the population size was 562 individuals (241 individuals from University of Isfahan, 189 from Isfahan University of Medical Sciences, and 132 from Isfahan University of Technology).

To calculate the final sample size, SPSS Sample Power software was used. Given the research targets, hypotheses and methods used to investigate these hypotheses, the regression model includes a maximim of eight independent variables that influence the dependent variable. Validity criteria include an error rate of 0.05 , a power higher than 0.80 , and an effect size of 0.10 . Based on this, the final sample size was calculated to be 130 (56 from University of Isfahan, 44 from Isfahan University of Medical Sciences, and 30 from Isfahan University of Technology), who were selected using stratified random sampling proportional to the sample size.

In order to collect the required data, the faculty members' research performance records were used, which were collated and adjusted based on a point system as part of an annual campaign for the evaluation and promotion of employees. The following were taken into consideration: monographs, articles published in current journals, papers presented at conferences, dissertations, scientific discoveries, patents and innovations, projects undertaken within and outside the university, and works of art. An analysis of employees' views of talent management was conducted using Eghbal et al.s 46-question questionnaire [Eghbal et al., 2016] based on Cheese et al's model [Cheese et al., 2008] with seven dimensions (defining and identifying talent needs, searching for talent, attracting talent, developing employee potential, strategically deploying talent, retaining talent, and optimizing talent management activities). In order to measure perceived organizational justice, Niehoff and Moorman's 21-question survey was used [Niehoff, Moorman, 1993] with the three dimensions of perceived organizational justice (distributive justice, procedural justice and interactional justice). Measurements were carried out with a 5-point Likert Scale (Strongly agree $=5$, agree $=4$, somewhat agree $=3$, disagree $=2$ and strongly disagree $=1$ ). The convergent validity of both questionnaires (AVE) was calculated to be higher than 0.5 and the reliability of both questionnaires using Cronbach's' alpha coefficient was calculated to be higher than 0.75 .

For a data analysis at the inferential statistics level, first, the main research hypothesis was examined using variance-based structural equation modeling and a special hypothesis using a one-way ANOVA and Scheffe 
Figure 2. Structural equation modeling of the effect of perceived talent management components on research performance, mediated by organizational justice

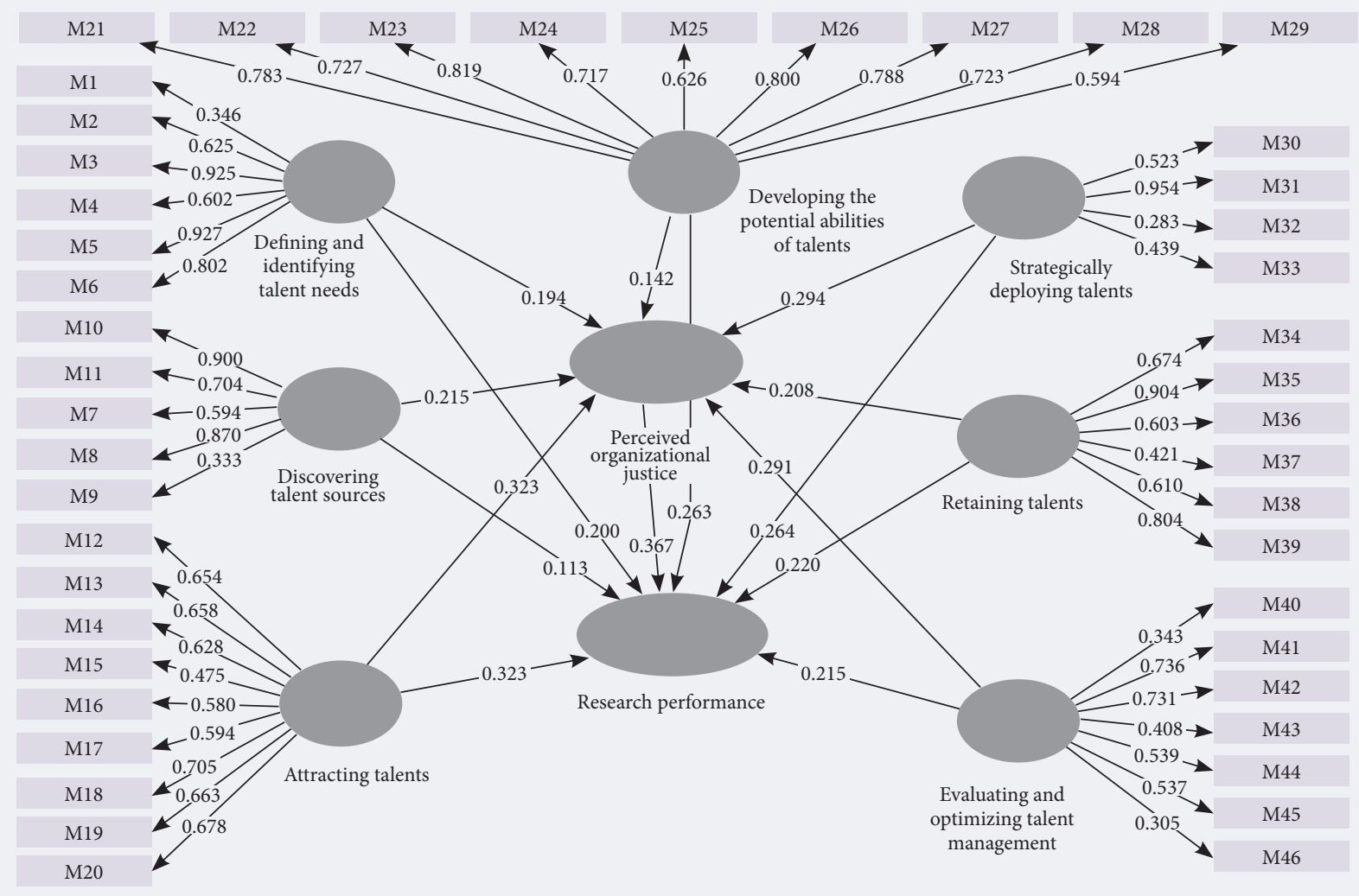

Source: compiled by the authors.

post hoc test with the help of SPSS and Smart PLS software. Testing a hypothesis with this approach helps the researcher treat variables as latent ones and therefore more precisely include measurement errors related to variables and consequently offer more precise estimates.

\section{Research Results and Findings}

The mediating role of perceived organizational justice between perceived talent management and research performance is calculated using structural equation modeling and is illustrated in Figure 2 and Tables 1 and 2. The results of structural equational modeling demonstrates an appropriate fit, in other words, it indicates data support for the research model. Therefore, it can be said that all the indicators are optimal state and demonstrate the appropriateness of structural equation modeling.

The values estimated in Table 2 show that: the components of talent management and perceived organizational justice explain a total of $61 \%$ of the total variance of the research performance variable. Given the classification of variables connected with the impact of the determination coefficient, the significance may be considered high. In other words, the components of the variables of talent management and perceived organizational justice can quite reliably explain the variance of research performance.

The indirect effect of the components such as those for attracting talent $(0.10)$, strategically deploying talent $(0.11)$, retaining talent $(0.12)$, and evaluating activity and optimizing talent management $(0.08)$ on research performance is statistically significant $(\mathrm{p} \leq 0.05)$. Therefore, the variable of perceived organizational justice plays a mediating role in the relationship between these talent management components and the variable

\section{Table 1. Significance of the indicators for evaluating} the overall structural equation model

\begin{tabular}{|l|c|}
\hline \multicolumn{1}{|c|}{ Indicator } & Value \\
\hline Goodness of Fit Index (GoF) & 0.43 \\
\hline Standardized Root Mean Square Residual (SRMR) & 0.07 \\
\hline Normed Fit Index (NFI) & 0.91 \\
\hline Source: compiled by the authors. & \\
\hline
\end{tabular}


Table 2. Estimate of total, direct and indirect effects of the components

of perceived talent management and organizational justice on research performance

\begin{tabular}{|c|c|c|c|c|c|c|c|c|c|}
\hline \multirow{3}{*}{ Independent variable } & \multirow{3}{*}{ Mediator } & \multirow{3}{*}{$\begin{array}{l}\text { Dependent } \\
\text { variable }\end{array}$} & \multirow{3}{*}{$\begin{array}{l}\text { The } \\
\text { coefficient of } \\
\text { determination }\end{array}$} & \multicolumn{6}{|c|}{ Estimate } \\
\hline & & & & \multicolumn{2}{|c|}{ Total } & \multicolumn{2}{|c|}{ Direct } & \multicolumn{2}{|c|}{ Indirect } \\
\hline & & & & Effect & p-value & Effect & p-value & Effect & p-value \\
\hline $\begin{array}{l}\text { Defining and identifying } \\
\text { talent needs }\end{array}$ & \multirow{7}{*}{ 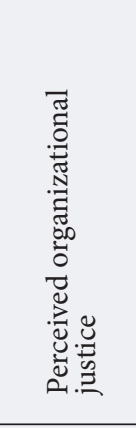 } & \multirow{8}{*}{ 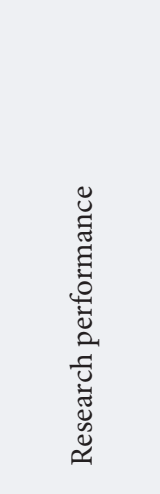 } & \multirow{8}{*}{0.61} & 0.23 & 0.012 & 0.20 & 0.015 & 0.03 & 0.634 \\
\hline Discovering talent sources & & & & 0.14 & 0.038 & 0.11 & 0.050 & 0.03 & 0.635 \\
\hline Attracting talents & & & & 0.42 & 0.001 & 0.32 & 0.001 & 0.10 & 0.032 \\
\hline $\begin{array}{l}\text { Developing the potential } \\
\text { abilities of talents }\end{array}$ & & & & 0.28 & 0.001 & 0.26 & 0.002 & 0.02 & 0.723 \\
\hline $\begin{array}{l}\text { Strategically deploying } \\
\text { talents }\end{array}$ & & & & 0.37 & 0.001 & 0.26 & 0.003 & 0.11 & 0.028 \\
\hline Retaining talents & & & & 0.34 & 0.001 & 0.22 & 0.010 & 0.12 & 0.020 \\
\hline $\begin{array}{l}\text { Evaluating and optimizing } \\
\text { talent management }\end{array}$ & & & & 0.30 & 0.001 & 0.21 & 0.012 & 0.08 & 0.049 \\
\hline $\begin{array}{l}\text { Perceived organizational } \\
\text { justice }\end{array}$ & - & & & 0.37 & 0.001 & 0.37 & 0.001 & - & - \\
\hline
\end{tabular}

of research performance. Taking into consideration the statistical significance of these components for faculty members' research productivity, the mediation of perceived organizational justice is estimated to be insignificant. The values of the indirect coefficients show the direct and weak mediation of organizational justice in the relationship between these components and the variable of research performance in the statistical population of the research. The indirect effect of the other components of perceived talent management, identifying and defining talent needs (0.03), discovering talent sources (0.03), and developing staff potential $(0.02)$ on research performance is not statistically significant $(p>0.05)$. Therefore, the variable of perceived organizational justice in the relationship between these components and research performance does not play a mediating role. In other words, the weak indirect effect of these components on research performance in the statistical sample is estimated to be caused by a sampling mistake or an error, and cannot be generalized to the statistical population of the research with a confidence of $95 \%$.

Hypothesis (1): there is significant variety in perceived talent management among the selected universities.

To investigate the hypothesis above, a one-way analysis of variance was used, the results of the test are reported in Table 3.

The values estimated in Table 3 show that the mean values of perceived talent management and the component of developing staff potential demonstrate that there are significant differences at the three universities of Isfahan $(05 / 0 \geq \mathrm{Sig})$.

In other words, the mean at Isfahan University of Medical Sciences is the highest and at University of Isfahan it is the lowest. Regarding other components of perceived talent management, there are no significant differences among the universities (sig $>0.05$ ).

In order to evaluate the difference between the mean values of perceived talent management and the components of developing staff potential, Scheffe's test was used. The test results are reported in Table 4.

The results of Scheffe's test demonstrate the preponderance of the mean values of perceived talent management among faculty members at the Isfahan University of Medical Sciences in comparison with the University of Isfahan and the Isfahan University of Technology. Also, the mean components of developing staff potential among faculty members of the Isfahan University of Medical Sciences is higher than at the other universities.

Hypothesis (2): there are significant differences in perceived organizational justice among the selected universities

To investigate the above hypothesis, a one-way analysis of variance was used, the results of the test are reported in Table 5.

The results of one way ANOVA test (f) in Table 5 show that there are no significant differences in the evaluation of organizational justice and its components among the selected universities (sig > 0.05). This allows us to state that the hypothesis that there are notable differences in the perceptions of instructors at different universities concerning organizational justice and its components was not confirmed.

Hypothesis (3): there are significant differences in research performance indicators among the selected universities.

To investigate this hypothesis, a one-way analysis of variance was used, the results of the test are reported in Table 6. 


\section{Table 3. Estimated one-way ANOVA to compare perceived talent management}

\begin{tabular}{|c|c|c|c|c|c|}
\hline Variable & University & Mean & $\begin{array}{l}\text { Standard } \\
\text { deviation }\end{array}$ & F-statistics & $\begin{array}{c}\text { Significance level } \\
\text { (Sig) }\end{array}$ \\
\hline \multirow{3}{*}{ Perceived talent management } & UI & 2.77 & 0.50 & \multirow{3}{*}{4.74} & \multirow[t]{3}{*}{0.012} \\
\hline & IUT & 2.91 & 0.44 & & \\
\hline & IUMS & 3.04 & 0.33 & & \\
\hline \multirow{3}{*}{ Defining and identifying talent needs } & UI & 3.37 & 0.67 & \multirow[t]{3}{*}{0.45} & \multirow[t]{3}{*}{0.638} \\
\hline & IUT & 3.41 & 0.68 & & \\
\hline & IUMS & 3.50 & 0.69 & & \\
\hline \multirow{3}{*}{ Discovering talent sources } & UI & 2.72 & 0.57 & \multirow[t]{3}{*}{$2 / 58$} & \multirow[t]{3}{*}{$0 / 083$} \\
\hline & IUT & 2.85 & 0.69 & & \\
\hline & IUMS & 3.05 & 0.84 & & \\
\hline \multirow{3}{*}{ Attracting talents } & UI & 3.00 & 0.69 & \multirow[t]{3}{*}{2.78} & \multirow[t]{3}{*}{0.066} \\
\hline & IUT & 3.11 & 0.69 & & \\
\hline & IUMS & 3.35 & 0.86 & & \\
\hline \multirow{3}{*}{ Developing the potential abilities of talents } & UI & 2.25 & 0.72 & \multirow[t]{3}{*}{35.59} & \multirow[t]{3}{*}{0.001} \\
\hline & IUT & 2.53 & 0.67 & & \\
\hline & IUMS & 3.03 & 0.21 & & \\
\hline \multirow{3}{*}{ Strategically deploying talents } & UI & 2.85 & 0.65 & \multirow[t]{3}{*}{0.33} & \multirow[t]{3}{*}{0.718} \\
\hline & IUT & 2.96 & 0.67 & & \\
\hline & IUMS & 2.88 & 0.51 & & \\
\hline \multirow{3}{*}{ Retaining talents } & UI & 2.50 & 0.56 & \multirow[t]{3}{*}{1.61} & \multirow[t]{3}{*}{0.203} \\
\hline & IUT & 2.63 & 0.52 & & \\
\hline & IUMS & 2.40 & 0.52 & & \\
\hline \multirow{3}{*}{$\begin{array}{l}\text { Evaluating and optimizing talent } \\
\text { management }\end{array}$} & UI & 2.88 & 0.36 & \multirow[t]{3}{*}{0.76} & \multirow[t]{3}{*}{0.471} \\
\hline & IUT & 2.95 & 0.35 & & \\
\hline & IUMS & 2.83 & 0.40 & & \\
\hline
\end{tabular}

The results of the one-way analysis of variance in Table 6 indicates that there are no significant differences between the research performance of faculty members at the selected universities $(\operatorname{sig}>0.05)$.

\section{Conclusion}

Given the fit of the conceptual research model, first, we assumed that the components of the talent management process directly or via perceived organizational justice affected the research performance of the faculty members at the selected public universities of Isfahan. After the analyses were performed, a model was built for measuring the effect of talent management and perceived organizational justice on research performance. The evaluation indicators of the overall structural equation model in general demonstrates empirical support for the theoretical research model. In other words, the data fit the model and the indicators show the appropriateness of the structural equation modelling. The components of talent management and perceived organizational justice explain a total of $61 \%$ of the variance in research performance, a quite high figure considering the extent of the coefficient's influence. In other words, the components of talent management and perceived organizational justice can mostly explain the variance in research performance.

The acquired data allow one to evaluate the indirect effect of the components of retaining talent (0.12), strategically deploying talent (0.11), attracting talent (0.10), and talent management and its optimization (0.08) on the research performance of faculty members, which is estimated to be average. Therefore, it can be said that the improvement of these components can lead to increased perceived organizational justice

\section{Table 4. Scheffe's test to compare the mean estimates of perceived talent management}

\begin{tabular}{|l|l|c|c|}
\hline \multirow{2}{*}{ Variable } & University & $\begin{array}{c}\text { Difference in } \\
\text { averages }\end{array}$ & $\begin{array}{c}\text { Significance level } \\
\text { (Sig) }\end{array}$ \\
\hline \multirow{5}{*}{ Perceived talent management } & UI & -0.14 & 0.402 \\
\cline { 2 - 4 } & IUT & -0.26 & 0.014 \\
\cline { 2 - 4 } & IUMS & -0.12 & 0.529 \\
\hline \multirow{2}{*}{ Developing the potential abilities of talents } & UI & -0.27 & 0.136 \\
\cline { 2 - 4 } & IUT & -0.78 & 0.001 \\
\cline { 2 - 4 } & IUMS & 0.50 & 0.003 \\
\hline Source: compiled by the authors.
\end{tabular}


Table 5. Results of one-way analysis of variance to compare mean perceived organizational justice among universities

\begin{tabular}{|c|c|c|c|c|c|}
\hline Variable & University & Mean & $\begin{array}{l}\text { Standard } \\
\text { deviation }\end{array}$ & F-statistics & $\begin{array}{c}\text { Significance level } \\
\text { (Sig) }\end{array}$ \\
\hline \multirow{3}{*}{ Perceived organizational justice } & UI & 2.82 & 0.42 & \multirow{3}{*}{0.28} & \multirow{3}{*}{0.758} \\
\hline & IUT & 2.89 & 0.43 & & \\
\hline & IUMS & 2.82 & 0.42 & & \\
\hline \multirow{3}{*}{ Distributive justice } & UI & 2.42 & 0.56 & \multirow[t]{3}{*}{0.38} & \multirow[t]{3}{*}{0.668} \\
\hline & IUT & 2.51 & 0.60 & & \\
\hline & IUMS & 2.39 & 0.62 & & \\
\hline \multirow{3}{*}{ Procedural justice } & UI & 2.80 & 0.43 & \multirow[t]{3}{*}{0.13} & \multirow[t]{3}{*}{0.875} \\
\hline & IUT & 2.85 & 0.45 & & \\
\hline & IUMS & 2.82 & 0.44 & & \\
\hline \multirow{3}{*}{ Interactional justice } & UI & 3.07 & 0.51 & \multirow[t]{3}{*}{0.25} & \multirow[t]{3}{*}{0.782} \\
\hline & IUT & 3.13 & 0.51 & & \\
\hline & IUMS & 3.05 & 0.46 & & \\
\hline
\end{tabular}

and, consequently, improved research performance. Meanwhile the weakening of these components can lead to a decline in perceived organizational justice and, consequently, decreased or weakened research performance.

It can be concluded that faculty members' perceived organizational justice is influenced by their perception of the talent management processes at their universities. In order to make faculty members feel that they are working at a university founded upon principles of justice, it is necessary to pay attention to the components of talent management, while the research performance of faculty members is influenced by talent management and perceived organization justice. These results are in line with the studies of [Lambert, 2003; Jiang, Iles, 2011; Gelens et al., 2014; Kagwiria, 2013; Salehzadeh, Labaf, 2011].

The higher the impact factors, the higher too is the influence of the relevant component. Therefore, according to Table 4, the impact of the component of retaining talent $(0.12)$ on research performance as mediated by perceived organizational justice is the highest. Given that retaining talent means keeping employee turnover rates low, which is the top priority at modern organizations, it therefore is recommended that university management boards provide: the necessary job security for their faculty members, fair salaries and bonuses, opportunities for career development, sufficient facilities and resources for employees' professional activities, and opportunities for staff to participate in international conferences by ensuring the necessary resources are in place.

The second most important component of research performance with the mediation of perceived organizational justice is the component of strategically deploying talent, with an impact factor of (0.11). Given that strategically deploying talent involves being able to select the right people for the right jobs at the right time, this allows an organization to effectively implement its strategies and prepare for future challenges and opportunities. University authorities are therefore recommended to ensure that employees' opportunities are in line with their job description, interests, knowledge and skills, and when deploying faculty members for educational or administrative tasks, management should consider the principle of competency.

The third component is attracting talent with an impact factor of (0.10). Given that attracting talent means the selection and employment of suitable individuals based on appropriate indicators, university authorities are recommended to pay attention to the communication skills of applicants, including their English proficiency, their ability to use information technologies. Management should also consider their skills and adaptability, including the ability to quickly learn and master new skills, their personality traits (decisiveness, observational skills, willingness to take risks, etc.) and their behavioral characteristics (whether they are hard workers, patient, and conscientious, etc.), and whether they are law-abiding. Finally, the specialized knowledge on individuals must be evaluated. All of the aforementioned traits of potential employees can be discovered during structured interviews with relevant experts. Furthermore,

Table 6. Results of one-way analysis of variance to compare the average research performance among universities

\begin{tabular}{|c|l|c|c|c|c|}
\hline \multirow{2}{*}{ Variable } & \multicolumn{1}{|c|}{ University } & Mean & $\begin{array}{c}\text { Standard } \\
\text { deviation }\end{array}$ & F-statistics & Significance level (Sig) \\
\hline \multirow{2}{*}{ Research performance } & UI & 5.30 & 0.88 & \multirow{2}{*}{0.96} & 0.390 \\
\cline { 2 - 4 } & IUT & 5.07 & 0.96 & & \\
\cline { 2 - 4 } & IUMS & 5.42 & 1.20 & & \\
\hline
\end{tabular}

Source: compiled by the authors. 
in order to bring in the best talent, it is necessary to thoroughly analyze the professional background of the applicants based on pre-determined criteria.

The fourth component influencing research performance through perceived organizational justice is the component of the evaluation and optimization of talent management with an impact factor of $(0.08)$. Given the significance of this component of talent management activities, university authorities are recommended to design a comprehensive evaluation system at the university that provides information about the strong and weak points of all parts of the talent management process (identification, attraction, deployment, development and retention).

Since the components of developing talent, discovering talent sources, and identifying and defining talent needs directly influence research performance, university management must ensure the improvement of education, research, communication, technology, and professional ethics, abd the development of skills. Management should also provide incentives for faculty members to study outside the university, they should subsidize participation in foreign academic programs. In order to develop talent, universities must have a written program of methodological recommendations though which faculty members at the mastery level could train individuals to replace them when they retire. With such a system in place, the information and experience of these faculty members would not be lost.

The search for talent involves the use of special methods for discovering the most gifted individuals within and outside of the university for their subsequent employment. Awareness and the formulation of a survey for talent begins with a clear understanding of the available specialists and the competencies that would be needed in the medium term (over the next five years). Then indicators should be determined for the personal and behavioral characteristics, the field of specialty, professional skills and key competencies of those applicants for teaching positions in order to select those individuals who will meet the university's needs to the greatest extent possible.

\section{References}

Adams J.S. (1963) Toward an understanding of inequity. Journal of Abnormal and Social Psychology, vol. 67, pp. $422-436$.

Avital M., Collopy F. (2001) Assessing Research Performance: Implications for Selection and Motivation (Sprouts Working Papers on Information Systems, 1(14)), Cleveland, OH: Case Western Reserve University, USA. Available at: http://sprouts.aisnet.org/1-14, accessed 26.10.2016.

Badri A.M., Abdulla H. (2004) Award of excellence in institutions of higher education: An AHP approach. Journal of Educational Management, vol. 78, no 4, pp. 224-242.

Cheese B., Thomas R., Craig E. (2008) The Talent Powered Organization: Strategies for Globalization, Talent Management and High Performance, London: Konan Page.

Eghbal F., Hoveida R., Siadat S.A., Samavatian H., Yarmohammadian M.H. (2016) Designing and codifying the faculty members' talent management process model for talent-based universities. Journal of General Management Research, vol. 22, pp. 9-11.

Gelens J., Hofmans J., Dries N., Pepermans L. (2014) Talent management and organisational justice: Employee reactions to high potential identification. Human Resource Management Journal, vol. 24, no 2, pp. 159-175. DOI 10.1111/1748-8583.12029.

Gething L., Larthaepin B. (2000) Strategies for promoting research participation among employed academics in the university sector. Nurse Educe Today, vol. 20, no 7, pp. 147-156.

Huselid M.A., Beatty R., Becke B.E. (2010) A Player or a Positions? The Strategic Logic of Workforce Management. Harvard Business Review, vol. 13, no 4, pp. 110-116.

Jiang T.T., Iles P. (2011) Employer-brand Equity, Organisational Attractiveness and Talent Management in the Zhejiang Private Sector, China. Journal of Technology Management, vol. 6, no 1, pp. 97-110.

Kagwiria R. (2013) Role of Talent Management on Organization Performance in Companies Listed in Naibobi Security Exchange in Kenya: Literature Review. International Journal of Humanities and Social Science, vol. 3, no 2, pp. 285-290.

Lambert E. (2003) The impact of organizational justice on correctional staff. Journal of Criminal Justice, vol. 31, no 2, pp. 155-168.

Levin S.G., Stephan P.E. (1991) Research productivity over the life cycle. Evidence for academic scientists. The American Economic Review, vol. 81, no 1, pp. 114-132.

McDowal A., Fletcher C. (2004) Employeed development: An organizatinal justice perspective. Personnel Review, vol. 33, no 1 , pp. 8-18.

McNabb N.S. (2009) The daily floggings will continue until morale improves: An examination of the relationships among organizational justice, job satisfaction, organizational commitment and intention to turnover (PhD Thesis), Norman, OK: University of Oklahoma.

Niehoff B.P., Moorman R.H. (1993) Justice as a mediator of the relationship between methods of monitoring and organizational citizenship behavior. Academy of Management Journal, vol. 36, no 3, pp. 527-556.

Ramsden P. )1994) Describing and explaining research productivity. Journal of Higher Education, vol. 28, no 6, pp. 207-226.

Rezaian A., Soltani F. (2009) Introduction to a comprehensive and systematic talent management model for the improvement of the individual performance of the oil industry's employees. Journal of Human Resource Management in the Oil Industry, vol. 3, no 8, pp. 49-55.

Salehzadeh L., Labaf H. (2011) Developing a model for strategic talent management for improvement of organizational performance. Journal of Tadbir, no 192, pp. 32-41.

Sayadi S., Mohammadi M., Nikpour A. (2011) Talent management - A key concept in the field of human resources. Journal of Work and Society, no 135, pp. 81-86.

Sweem S.L. (2009) Leveraging employee engagement through a talent management strategy: Optimizing human capital through human resources and organization development strategy a field study (PhD Thesis), Lisle, IL: Benedictine University.

Zainab A.N. (2000) Publication productivity, focus on institutional, collaborative and communicational correlates: A review of literature. Malaysian Journal of Library and Information Science, vol. 5, no 1, pp. 53-94. 